\title{
The Role of Management of The Jakarta Arts Center Planetarium And Observatory In Innovation And Delivering Information To The Community
}

\author{
Ida Royani Damayanti ${ }^{1}$, Kornelia Johana Dacosta ${ }^{2}$ \\ \{ida.damayanti@undira.ac.id ${ }^{1}$,kornelia.johana@undira.ac.id² \\ Universitas Dian Nusantara Jakarta, Indonesia ${ }^{1}$, Universitas Dian Nusantara Jakarta, Indonesia ${ }^{2}$
}

\begin{abstract}
Human interest in the movement of celestial bodies and their beauty has been recognized as inseparable from society since the Ancient Egyptian Civilization was at its zenith still victorious, similarly, the Indonesian. The Jakarta Special Capital Region (DKI) Government provides facilities for the general public and students to make tourist and educational visits, where visitors can learn about astronomy. as well as seek recreation. However, the current problem is the Covid-19 pandemic will certainly have an impact on the number of visitors both from and outside Jakarta. This makes it more difficult for public relations (PR) management to develop strategies to attract visitors, such as giving away free masks and providing hand sanitizers. The objective of this study is to determine PR innovations at the Planetarium and Observatory of the Jakarta Arts Center in conveying information to potential visitors from Jakarta and outside Jakarta during the Covid-19 pandemic. The role of PR includes how management will develop and implement the planned innovations. This study uses a postpositive paradigm (qualitative), with a descriptive method approach, which presents an overview of the performance of the Planetarium and Observatory PR management using field data obtained through focused in-depth interviews with visitors.
\end{abstract}

Keywords: Public Relations Management, Innovation, Planetarium

\section{Introduction}

The development of global tourism has experienced a sharp downturn since the outbreak of the Covid-19 pandemic which has severely affected the entire world, including Indonesia. Almost all tourist destinations, attractions and facilities in Indonesia have been impacted, accompanied by significant job losses of workers in the sector. Jakarta is the region with the highest number of Covid-19 cases in Indonesia, with a reported total of 9,971 cases (Source: BBC News Indonesia, June 21, 2020). Following the Large-Scale Social Restrictions (PSBB) policy introduced by the Jakarta Special Capital Region Government, people previously reluctant to visit popular tourist locations are now expected resume their outings. However, these visits will be accompanied by official requirements to comply with the Covid-19 protocol such as maintaining a safe distance 
between people (social distancing), wearing masks and observing personal hygiene requirements by carrying hand sanitizers in order to maintain public safety.

Obviously, as one of the most visited local and national tourist destinations, the Planetarium has experienced the impact of the Covid-19 pandemic, as a result of being obliged to close namely by closing all facilities for visitors while the Large-Scale Social Restrictions were in force. However, now that the PSBB have been relaxed, it is hoped that visitors will again be able to enjoy the Jakarta Planetarium facilities. The planetarium is an exhibition hall or theatre with a closed semi-circular dome-shaped roof which functions as a screen, with a principal projector used to demonstrate the position and movement of stars and celestial bodies which are projected onto a screen in the dome, to the accompaniment of music. The planetarium is also an educational which uses a projector to display the location and circulation of the planets in the solar system, including the sun at the centre of the system [1]
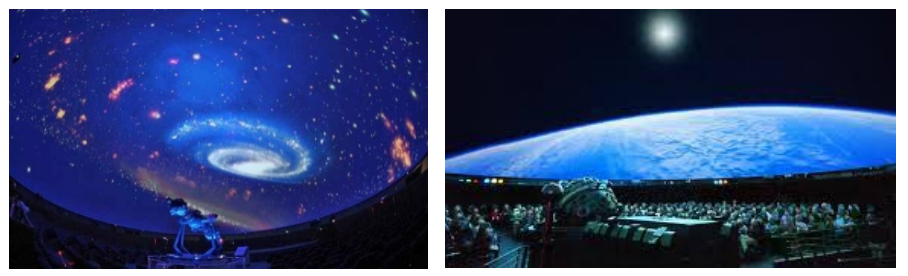

The planetarium has two service functions intended for special and general purposes. The special planetarium is used for education and research, while the general planetarium is open to the general public to provide both education and recreation. The planetarium management has plans to improve the facilities by developing programs aimed at the general public which will provide shows on a predetermined schedule. Another set of programs targeted at schools for various groups of students, starting from kindergarten and progressing from elementary school to high school. Other programs are provided for tourist and religious groups and given in dedicated rooms.

At an interview, Mr. Eko, the PR manager of the Jakarta Arts Center Planetarium and Observatory stated: "visitors to the planetarium are divided into two categories, the first is for students at all levels, from kindergarten to college, the second is for the general public. Tuesday to Friday is for students and Saturday through Sunday for the general public. The average age for student visitors from is 6 to 12 years, whilst for the general public on Saturdays and Sundays, the average age of visitors is more than 15 years. 

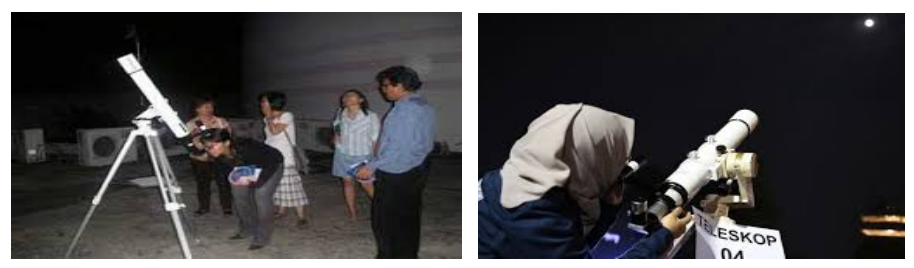

Mr Eko went on to explain that management is constantly introducing innovations to keep up with technological developments, One such innovation is to adjust robotic tools used robotic which can automatically modify a mapping location and the Planetarium is currently preparing a proposal for a digital processing tool. To provide information to the general public, the Planetarium uses both offline and online media such as its own website and Facebook for interactive communications between the Planetarium and outside parties. Through the website, Planetarium responds to comments, questions, criticisms and suggestions by email and telephone, both landline and mobile. According to Mr. Eko and Mr. Aziz, the operators of the Planetarium website are well prepared to respond to questions from the general public and the management is well aware that effective communications are a prerequisite to achieving overall objectives. Research Focus, The focus of this research is to: (i) analyze how the role of public relations management can be developed to assist the Jakarta Arts Center Planetarium and Observatory to prepare and provide information to the general public, and (ii) evaluate the performance of management in dealing with preparing and providing this information. Research Objectives The purpose of this study is to describe the role of the the Jakarta Arts Planetarium and Observatory Planetarium Public Relations management in innovating and to determine the categories of information concerning its activities in order to stimulate the interest of visitors following the relaxation of the Large-Scale Social Restrictions policy delivery. It is hoped that this research will be useful to all interested parties by providing: (i) academic benefits, by extending the development of knowledge and providing a reference for students; (ii) practical benefits, by improving management performance in promoting educational tourism in Indonesia and increasing the understanding of the importance of packaging future educational tours as a benchmark for the country, and (iii) social benefits, through this research assisting Indonesians people to increase their interest in educational tourism so that the country's human resources can compete in the international arena and also increase the level of education of astronomy in Indonesia.

\section{Literature Review}

Basic Management Concepts, The word "management" comes from the old French noun "management", which means "the art of executing and organizing. The term "management" also 
comes from the noun "management" which comes from the verb "to manage" which means to manage or administer. Scientific management always tries to manage systematically in order to understand how and why humans should work together in order to achieve goals and create a system of cooperation beneficial to mankind. Meanwhile, the definition of management according to [2] I that "management" comes from the verb "to manage" which means to regulate, what is regulated, the goal set, why should it be regulated, who regulates it, and how to organize it.

Basic Concepts of Public Relations, The concept of public relations develops by following every change that occurs in the environment, especially in today's open society. Public relations activities are the most important part in an organization in providing information to the general public and effective communication skills are required to convey this information. Public relations certainly cannot be separated from communication. According to The International Public Relations Association, Public Relations is a management function which is implemented in a continuous and planned manner. Because of the importance of communication in Public Relations, one can trace it through the various functions and activities of public relations, one of which is the function of communication to convey information. Information conveyed by PR must be informative, educative, and persuasive. Therefore, information provided by public relations must also be considered with the objective of attracting public interest.Public relations as "the management function which establishes and maintains mutually beneficial relationships between an organization and the public on whom its success or failure depend." What can be interpreted by Public Relations may be interpreted as a management function which can determine the success or failure of an organization to build and maintain mutually beneficial relationships between the organization and the general public.[3]

The development of communication in the world, especially in Indonesia, is very fast, especially in the field of Public Relations or Public Relations since 17 August 1945 when President Ir. Soekarno decided to postpone the PPKI session to provide press statements regarding the Presidential election before formulating the Constitution. So since then the development of Public Relations has been quite rapid.

Etymologically, "Hubungan Masyarakat" in Indonesian is translated from the English word which means Public Relations (PR). According to [4] Public Relations is a two-way communication between an organization and the general public in order to support the functions and objectives of management by fostering cooperation and fulfilling common interests. In public relations activities, there is a communication activity. In addition, the role of Public Relations is needed in an organization/company to provide information on its objectives and activities to the general public.

According to Rosady Ruslan (2005: 10) PR has four important roles: (i) as a communicator in charge of providing information between the organization or institution represented and the general public; (ii) Fostering a positive and mutually beneficial relationship between the organization and the general public; 3) a back-up to management, meaning support to the management function of an organization or company, and (iv) 4) developing a corporate image, whereby the role of Public Relations seeks to create a positive image for the organization.

Definition of Public Relations Management, Public Relations Management in general can be interpreted as a management function which specifically integrates the interests of an institution or organization with its public; in the case of this study by providing any and all information which should be made known to the community by developing using tourism education services related 
to the activities of the Jakarta Arts Center Planetarium and Observatory so that the general public and educational institutions can be up-to-date with the latest activities and do not need to call or go directly to the Planetarium and Observatory to ask about tour programs. [5] define public relations activities as communication activities, "the management of communication between an organization and its public". [6] defines "public relations as planned, persuasive communications designed to significant influence the public".[7]

Ruslan also stated that public relations management is a two-way communication between an institution and the community to carry out various planning, organizational, implementing, and evaluation activities to achieve organizational goals. The role of PR is to support the functions of company management to achieve common goals and it depends on the ability to utilize the resources of the organization. Thus, as a public relations practitioner and PR manager, they must have the ability to coordinate all existing resources such as: (i) Technical Management Skills, and (ii) Managerial Skills. As expressed by [8] Communication and Culture Bachelor Association Journal a public relations practitioner must develop into a manager who has "managerial skills" or "technical skills" in communicating as competence skills.

[9]in his research entitled Basics of Public Relations states that the role of Public Relations can be divided into two parts, the managerial role (communications management role) and technical role (communications technical role). The two roles are divided into the following four sub-roles roles: (i) Expert Prescriber Communication, a Public Relations practitioner with substantial experience and ability to help find solutions in solving relationship problems with the general public; (ii) Problem Solving Process Facilitator, meaning the role of a facilitator in the problem-solving process, e.g. public relations is involved in all management (crises), meaning the person becomes a team member, or even a leader, in crisis management; and (iii) Communication Facilitator, acting as a communicator or mediator so that management is aware of what the public wants and expects, whilst the person is also required to be able to explain again the wishes, policies and expectations of the organization to the public so that with this reciprocal communication mutual understanding, trust, respect, support and tolerance can be created between both parties; and (iv) Public Relations Technical Communicator providing technical services, although the policy and decision for which technical communication are needed are not his decision, but the decision of management and public relations.

Role of Public Relations Management, the role of Public Relations is very much needed in an organization/company as a bridge between the company and the public or between management and the internal public in order to achieve a mutual understanding between the two parties. [10] Public Relations acts as a communicator when management deals with its employees. Management is a process that includes the following issues; i) planning which includes setting standard objectives, determining rules and procedures, making plans and predicting events. The Planetarium must know why a plan is necessary.

The purpose of a plan is to implement programs with an increased the likelihood of achieving its goals so that better decisions can be made in the future. Therefore, organizational planning must be active, dynamic, sustainable and creative, so that management not only reacts to its environment, but becomes an active participant in the business world, for example the Planetarium is not only intended for educational tourism but may also be used for other activities such as religious functions and rentals for weddings and other social functions. ii) Organization, meaning giving specific tasks to each party, forming teams, delegating and establishing a communication 
system, and coordinating the work of each employee in a compact and organized team. iii) Actuating is a goal which may only be achieved if there is managerial direction. This direction is useful as a basic guide for workers in carrying out their duties in order to achieve goals. iv) Control (controlling), this final function of this management includes the preparation of a standard of quality and quantity of results, both in the form of products and services provided by the company/organization in order to achieve goals, productivity and create a positive image. v) Communicating (communicating) includes submitting planned programs to the public.

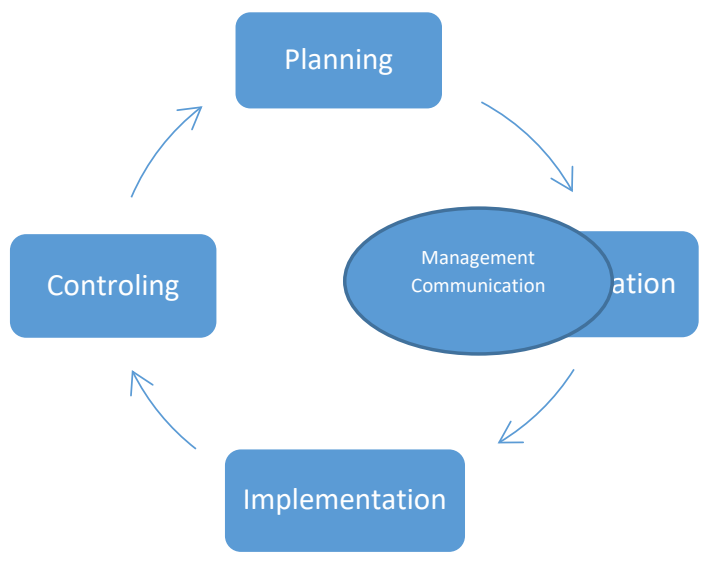

General Role of Public Relations Management

George R. Terry has defined these functions as "POAC" [11]

Public Relations Practitioners (Public Relations Officers) use management concepts to facilitate the implementation of their duties, such as making plans, making preparations, taking action and communication, and closing with a control measure called evaluation.

\section{Research Method}

Methodology This research will be conducted using qualitative research methods, with a descriptive approach because this approach is best able to make observations in a natural and social setting. The purpose of researchers using descriptive research is to produce an accurate picture of a phenomenon and the mechanism of a process, which will explain a set of stages of the research process. Research Focus, the focus of this research is how the role of Planetarium and Central Observatory Public Relations management may introduce innovation and convey to the public information which is related to planning, organization, job descriptions and communication method. Preparation of a quality standard. Research Locations,this research will be carried out at 
the Jakarta Arts Center Planetarium and Observatory located in Taman Ismail Marjuki, Central Jakarta on Jalan Cikini Raya. Determination of Research Subjects (Informants). To obtain accurate information, there are several criteria to be considered, such as the research subject being determined based on the person who is considered to know the most about the information required in the study, so that it will be easier for researchers to trace the activity being studied. The subjects of this research are employees of the Public Relations department of the Jakarta Arts Center Planetarium and Observatory who prepare and provide information to the general public, as well as visitors to the facility. To determine the researched subjects of this study the following purposive sampling techniques are used; (i) The subject is long and intensive with an activity or activity which is the target or attention of the researcher. (ii) Subjects who are fully and actively concerned with the environment or activities which are the target or attention of researchers. (iii) Subjects having sufficient information, time and opportunity to be questioned. (iv) Subjects who are or live in the target area, with the possibility of the researcher using snowball sampling if the information obtained from the field is not completed, for example the researcher will interview visitors to the educational tourism object of the Planetarium and observatory.

\section{Tabel 1.}

\begin{tabular}{llll}
\hline No & Name & Information & Date of interview \\
\hline 1. & Eko & PR & \\
2. & Aziz & PR & \\
3. & Initial & Visitor & \\
4. & Initial & Visitor & \\
5. & Initial & Visitor & \\
\hline
\end{tabular}

List of Informant Tables

Data Collection Techniques, data collection techniques used in this study are; (i) Observation of participants because researchers will be directly involved to determine the level of understanding of the subject about management performance in the Jakarta Arts Center Planetarium and Observatory Public Relations Department. Through observation, researchers may see things that are not observed by the subject, especially people who are in research situations. Information obtained from observations includes place, person, activity, object, action, event or event, time, feeling. The reason the researcher makes observations is to present a realistic picture of behavior or events, to answer questions, to help understand human behavior, and to evaluate what will be included in the conclusion. (ii) Interviews conducted in this study use semi-structured interviews, by asking several questions of the data source. (iii) Documentation, the researcher will look for data in the form of documents from interested parties.

Types of Data Sources,types of data sources obtained are from two sources: namely primary and secondary data sources. Primary data are obtained through interviews with researchers, Secondary data are obtained by researchers through supporting documents related to the research. Data Analysis Techniques, Based on the picture below, researcher perform data collection techniques using; (i) Data reduction: the process of selecting the abstracting of data obtained from research locations. (ii) Data presentation, (data display) in qualitative research, data presentation in the form of brief descriptions, charts, relationships between categories. (iii) Conclusions / verifications are verified during the research. 
In addition to using data reduction, researchers may also use triangulation techniques to check the validity of the data. According to [12] triangulation is a technique of checking the validity of data which uses something else in comparing the results of interviews with the object of research. Therefore, the researcher will later use data triangulation, which means to check the validity of the data through cross-check interviews using data from different research locations, such as information from visitors who have never visited the Planetarium and observatory so that researchers may draw a valid conclusion regarding program information. program carried out by the object under study.

\section{Result and Discussion}

In maintaining an agency, of course, the agency must continue to innovate and deliver interesting information to the public. Innovation and the delivery of information are one of the important roles for a public relations officer to maintain an agency, this can be seen through the effectiveness of public relations from the agency, in this research on the Planetarium and Observatory of the Jakarta Arts Center, in fact several main principles for achieving public relations effectiveness are indeed carried out. by the Jakarta Arts Center Planetarium and Observatory Manager. The Jakarta Arts Center Planetarium and Observatory overcomes the problem of the decline in visitors, namely by visiting schools in DKI Jakarta to introduce the world of astronomy to elementary school students, this is able to attract visits like the table above, that after the Plantarium was closed for one month in the following month, visitors both individually and in groups experienced a quite rapid increase. Regarding the innovations made by the Planetarium, Planetarium Jakarta not only focuses on the Planetarium but also has an Observatory, therefore the Planetarium opens a session for Observation of Celestial.

Delivery of Information, they do not stop at just making innovations, the Planetarium and Observatory of the Jakarta Arts Center also conducts an activity called Pick Up Ball to attract school children to visit. ubmission of information between the Planetarium and Observatory of the Jakarta Arts Center and external parties is carried out through the Website and Facebook. On the Jakarta Arts Center Planetarium and Observatory Website, external parties can provide questions, criticisms and suggestions to email and numbers that can be contacted to find out information related to the Planetarium. Meanwhile, through Facebook the Planetarium and Observatory of the Jakarta Arts Center provide more communicative information, such as schedule changes to information about celestial phenomena. The Communication Technician is tasked with providing services in the technical field, the PR of the Planetarium and Observatory of the Jakarta Arts Center always provides updates by providing information online on the Facebook Planetarium and offline direct submissions which are affixed to the entrance to the Planetarium. The Communication Technician also delivers the monitoring schedule via Facebook Planetarium and the Planetarium Website.

Based on data obtained from the results of in-depth interviews or In Depth Interviews conducted with 2 key informants and observing the Taman Ismail Marzuki Planetarium, in this section the researcher describes and analyzes the data obtained qualitatively. In this study, researchers analyzed data using data triangulation techniques by comparing observational data 
with interview data. Based on the results of the above research, the researcher can explain that the Role of Public Relations at the Planetarium and Observatory of the Jakarta Arts Center in Innovation and Information Delivery is quite effective in carrying out its role as a PR by referring to the four roles of public relations according to Cutlip. [13]

\section{Conclusion}

1. The four roles of Public Relations according to Cutlip are as Expert Prescriber, Problem Solving Facilitator, Facilitator Communication, and Communication Technician. Broadly speaking, it has been carried out by the Jakarta Arts Center's Planetarium and Observatory Public Relations.

2. In carrying out the four roles, some are dominant but some are not. There are two dominant roles, namely; The role as a Communication Facilitator is a fairly dominant role carried out in conveying information to the public using the Website, Facebook and direct delivery, both attached to the entrance to the Planetarium. The second dominant role is Problem Solving Facilitator where the Planetarium solves the problems that occur in a fairly effective manner, such as;

a. Decreasing visitors, the Planetarium conducted a program to visit schools in order to attract the interest of the public to visit the Planetarium.

b. Planning for Innovation, Planetarium Public Relations has made a request to change the equipment into robotic.

c. In delivering information, the Planetarium has delivered information quite well, namely via Facebook which is quite communicative by replying to comments from the community and a website which is quite helpful with a fast response, which is a maximum of $2 \times 24$ hours.

\section{References}

[1] E. Lantz, "Planetarium of the Future," Curator Museum J., 2011, doi: 10.1111/j.21516952.2011.00093.x.

[2] Stie Trisakti, "Manajemen humas (public relations) di lembaga pendidikan," Medis Bisnis, 2011.

[3] L. Laketa and M. Laketa, "VERTICAL MANAGEMENT IN THE FUNCTION OF SALES," Cas. ZA Ekon. I Trz. Komun., 2016, doi: 10.7251/EMC1602274L.

[4] C. T. Thibodeau, "Effective communications," in The Professional Protection Officer, 2010.

[5] J. Macnamara, "Emerging international standards for measurement and evaluation of public relations: A critical analysis," Public Relations Inq., 2014, doi: 10.1177/2046147X14521199. 
[6] J. Grunig, "Research in Public Relations: current Status and New Directions," Anàlisi Quad. Comun. i Cult., 2006.

[7] S. Syamsurizal, "Strategi Komunikasi Persuasif dalam Aktivitas Pemasran," J. Lentera Bisnis, 2017, doi: 10.34127/jrlab.v5i2.39.

[8] T. Yuniarsih, Suwatno, and Adman, "Manajemen Sumber Daya Manusia," 2018.

[9] G. M. Broom and D. M. Dozier, "Advancement for public relations role models," Public Relat. Rev., 1986, doi: 10.1016/S0363-8111(86)80039-X.

[10] S. Gilaninia, M. Taleghani, and M. E. Mohammadi, "The Role of Public Relations in Organization,” Niger. Chapter Arab. J. Bus. Manag. Rev., 2013, doi: 10.12816/0003699.

[11] 2011:3) George R Terry, dalam buku Principles of Management (Sukarna, "George R Terry, dalam buku Principles of Management (Sukarna, 2011:3)," J. Chem. Inf. Model., 2019, doi: 10.1017/CBO9781107415324.004.

[12] S. Syahrum., "Metodologi Penelitian Kuantitatif," KOMUNIKASI PENELITIAN KUANTITATIF Program Studi Jurnalistik \& Humas. 2014.

[13] G. M. Broom and B.-L. Sha, Cutlip and Center's Effective Public Relations. 2013. 